\title{
Removal of copper and fluoride from wastewater by the coupling of electrocoagulation, fluidized bed and micro-electrolysis (EC/FB/ME) process
}

\author{
Vo Anh Khue ${ }^{1,2, ~ *, ~ L i ~ T i a n ~ G u o ~}{ }^{1}$, Xu Xiao Jun , Yue Xiu Lin ${ }^{1}$, Peng Rui Hao \\ ${ }^{1}$ Faculty of Environmental Science and Engineering, Kunming University of Science and Technology, Yunnan 650500, China \\ ${ }^{2}$ Faculty of Chemical Engineering, Tuy Hoa Industrial College, Phu Yen 620900, Vietnam
}

\section{Email address:}

khue_80@yahoo.com(V. A. Khue)

\section{To cite this article:}

Vo Anh Khue, Li Tian Guo, Xu Xiao Jun, Yue Xiu Lin, Peng Rui Hao. Removal of Copper and Fluoride from Wastewater by the Coupling of Electrocoagulation, Fluidized Bed and Micro-Electrolysis (EC/FB/ME) Process. American Journal of Chemical Engineering. Vol. 2, No. 6, 2014, pp. 86-91. doi: 10.11648/j.ajche.20140206.13

\begin{abstract}
Copper and fluoride ions were removed from wastewater by the coupling of electrocoagulation, fluidized bed and micro-electrolysis (EC/FB/ME) process. The results indicate that the use of aluminum electrode for simultaneous removal of copper and fluoride ions is better than iron electrode. By the orthogonal experiments study of the main factors influencing the efficiency of the treatment process, the best control parameters of this process were achieved in four aluminum electrodes, an initial $\mathrm{pH}$ of 5.0, a hydraulic retention time of 30 minutes, an applied voltage of $5 \mathrm{~V}$, a mass of iron-carbon $(\mathrm{Fe} / \mathrm{C})$ of $45 \mathrm{~g}$ and the particle diameter of $\mathrm{Fe} / \mathrm{C}$ of $20-27$ mesh. With these conditions and the initial concentration of ions of $50 \mathrm{mg} / \mathrm{L}$, the residual concentration of copper and fluoride are $0.205 \mathrm{mg} / \mathrm{L}$ and $2.936 \mathrm{mg} / \mathrm{L}$, respectively. The EC/FB/ME process is suitable for treatment of wastewater that fluoride concentration is less than $50 \mathrm{mg} / \mathrm{L}$ and copper concentration is less than $200 \mathrm{mg} / \mathrm{L}$. This process was successfully applied to the treatment of a smelting wastewater sample.
\end{abstract}

Keywords: Electrocoagulation, Micro-Electrolysis, Iron Electrode, Aluminum Electrode, Copper and Fluoride Ions, Fluidized Bed

\section{Introduction}

Industrial effluents from electroplating, metallurgy and mining contain high concentration of fluoride, lead, zinc and copper, etc. The wastewater treatment methods such as biological method, membrane method, adsorption method are unsuitable for treating large amounts of wastewater with high concentration of heavy metal and fluoride ions. Currently, the most popular method for treating of heavy metal and fluoride ions is precipitation method by alkaline solutions. However, the treated wastewater by this method has some disadvantages such as deposition of coagulants is slow, the residual concentration of heavy metal ions is usually larger than $1 \mathrm{mg} / \mathrm{L}$ and fluoride removal efficiency is low, etc [1]. Thus, the study of a new method for simultaneous removal of heavy metal and fluoride ions from wastewater is necessary.

In this paper, the use of $\mathrm{EC} / \mathrm{FB} / \mathrm{ME}$ process for simultaneous removal of copper and fluoride ions from wastewater was studied. This process is the simultaneous combination of electrocoagulation, fluidized bed and micro-electrolysis. Where the electrocoagulation method used iron electrodes and aluminum electrodes. The micro-electrolysis method used particles of iron-carbon (Fe/C). The fluidized bed method was used to provide oxygen for the treatment system and prevent the clumping of $\mathrm{Fe} / \mathrm{C}$, therefore, reduce the passivation problem of the particles of $\mathrm{Fe} / \mathrm{C}$. The mechanism of $\mathrm{EC} / \mathrm{FB} / \mathrm{ME}$ process is summarized as follows as [2-4]:

* At the anode surface: The possible reactions that may occur on the anode surface (including iron or aluminum anode and iron of $\mathrm{Fe} / \mathrm{C}$ ) are metal dissolution and oxygen evolution. The half-cell reactions may be expressed as:

$$
\begin{array}{r}
A l \rightarrow A l^{3+}+3 e^{-}, \mathrm{E}^{0}\left(\mathrm{Al}^{3+} / \mathrm{Al}\right)=-1.66 \mathrm{~V} \\
F e \rightarrow \mathrm{Fe}^{2+}+2 e^{-}, \mathrm{E}^{0}\left(\mathrm{Fe}^{2+} / \mathrm{Fe}\right)=-0.44 \mathrm{~V} \\
2 \mathrm{H}_{2} \mathrm{O} \rightarrow \mathrm{O}_{2} \uparrow+4 \mathrm{H}^{+}+4 e^{-}, \mathrm{E}^{0}\left(\mathrm{O}_{2} / \mathrm{H}_{2} \mathrm{O}\right)=1.23 \mathrm{~V} \\
2 \mathrm{OH}^{-} \rightarrow \mathrm{O}_{2} \uparrow+2 \mathrm{H}^{+}+4 e^{-}, \mathrm{E}^{0}\left(\mathrm{O}_{2} / \mathrm{OH}^{-}\right)=0.40 \mathrm{~V}
\end{array}
$$

* At the cathode surface: including iron or aluminum 
cathode and carbon of $\mathrm{Fe} / \mathrm{C}$. The half-cell reactions can be represented as reduction in the cathode:

$$
\begin{gathered}
2 \mathrm{H}^{+}+2 e^{-} \rightarrow \mathrm{H}_{2} \uparrow \text { (acidic), } \mathrm{E}^{0}\left(2 \mathrm{H}^{+} / \mathrm{H}_{2}\right)=0.00 \mathrm{~V} \\
2 \mathrm{H}_{2} \mathrm{O}+2 e^{-} \rightarrow \mathrm{H}_{2} \uparrow+2 \mathrm{OH}^{-} \text {(neutral to alkaline) } \\
\mathrm{E}^{0}\left(2 \mathrm{H}^{+} / \mathrm{H}_{2} \mathrm{O}\right)=-0.83 \mathrm{~V} \\
\mathrm{O}_{2}+4 \mathrm{H}^{+}+4 e^{-} \rightarrow 2 \mathrm{H}_{2} \mathrm{O}(\text { acidic }), \mathrm{E}^{0}\left(\mathrm{O}_{2} / \mathrm{H}_{2} \mathrm{O}\right)=1.23 \mathrm{~V} \\
\mathrm{O}_{2}+2 \mathrm{H}_{2} \mathrm{O}+4 e^{-} \rightarrow 4 \mathrm{OH}^{-}(\text {neutral to alkaline }) \\
\mathrm{E}^{0}\left(\mathrm{O}_{2} / \mathrm{OH}^{-}\right)=0.40 \mathrm{~V}
\end{gathered}
$$

* At the solution: oxidation of $\mathrm{Fe}^{2+}$ generates $\mathrm{Fe}^{3+}$.

$$
4 \mathrm{Fe}^{2+}+\mathrm{O}_{2}+4 \mathrm{H}^{+} \rightarrow 4 \mathrm{Fe}^{3+}+2 \mathrm{H}_{2} \mathrm{O} \text { (acidic) }
$$

$4 \mathrm{Fe}^{2+}+\mathrm{O}_{2}+2 \mathrm{H}_{2} \mathrm{O} \rightarrow 4 \mathrm{Fe}^{3+}+4 \mathrm{OH}^{-}$(neutral to alkaline) (11)

$\mathrm{Fe}^{2+}, \mathrm{Fe}^{3+}$ and $\mathrm{Al}^{3+}$ react with $\mathrm{H}_{2} \mathrm{O}$ and $\mathrm{OH}^{-}$group to generate coagulants in the wastewater such as $\mathrm{Al}(\mathrm{OH})_{3}$, $\mathrm{Al}(\mathrm{OH})^{2+}, \mathrm{Al}(\mathrm{OH})_{2}{ }^{+}, \mathrm{Fe}(\mathrm{OH})_{2}, \mathrm{Fe}(\mathrm{OH})_{3}, \mathrm{Fe}(\mathrm{OH})_{4}{ }^{-}$, etc. These coagulants are co-precipitation and adsorption with the heavy metal and fluoride ions. So, they separate heavy metal and fluoride ions from wastewater.

Recently, the electrocoagulation method and the micro-electrolysis method are widely used in wastewater treatment. Electrocoagulation has been successfully performed for decolorization treatment of dyes, remediation of the dye-house wastewaters [5], treatment of oil wastes [6], heavy metal bearing effluents [7], etc. The micro-electrolysis method has been successfully performed for improving the biodegradability before the bioprocess treatment [4], treatment of lead and zinc smelting wastewater [8], treatment of electroplating wastewater [9], etc. However, the disadvantages of electrocoagulation are large energy consumption and many sludges. The disadvantages of micro-electrolysis are speed slow, low efficiency, etc. Therefore, the study of a new process with the combination of electrocoagulation, fluidized bed and micro-electrolysis will promote the advantages and reduce disadvantages of each method.

\section{Materials and methods}

\subsection{Materials}

$\mathrm{CuSO}_{4} .5 \mathrm{H}_{2} \mathrm{O}, \mathrm{NaF}, \mathrm{HCl}, \mathrm{H}_{2} \mathrm{SO}_{4}, \mathrm{HNO}_{3}, \mathrm{NaOH}, \mathrm{KCl}$ are analytical grade (Merck). Specifications of iron and aluminum electrodes are: long $28 \mathrm{~cm}$, wide $4.7 \mathrm{~cm}$ and thick $1 \mathrm{~mm}$. The particle of $\mathrm{Fe} / \mathrm{C}$ bought at Weifang Yan Wal Yun $\mathrm{Pu}$ environmental technology company, China.

The actual wastewater was obtained from a smelting unit at Mengzi, Yunnan, China.

The equipments were used in the experiment include: self-made kit as Figure 1, water velocity meter LZB-25, water pump AP 1600, atomic absorption spectroscopy AA240FS, machine transforms from alternating current to direct $\mathrm{KGF} 50 \mathrm{~A} / 50 \mathrm{~V}$, and other equipments.

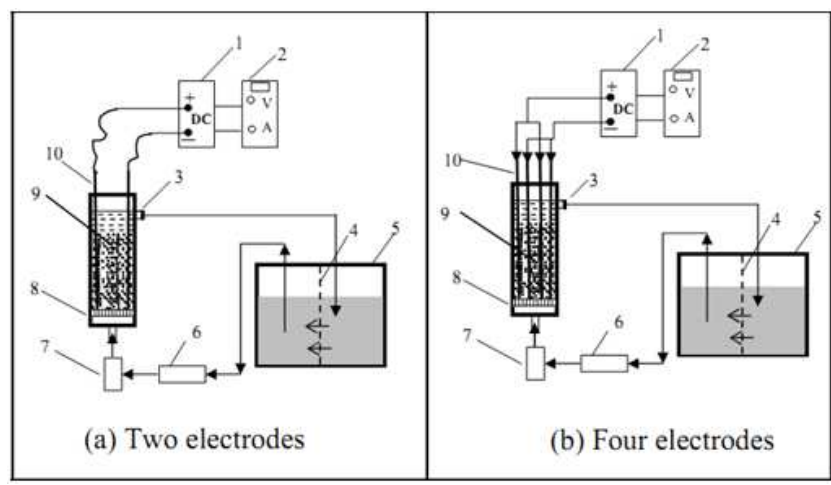

Figure 1. Schematic diagram of $E C / F B / M E$ process

(1 - DC power supply, 2 - adjustment of voltage, 3 - water outlet, 4 - bulkhead, 5 - wastewater tank, 6 - water pump, 7 adjustment of wastewater speed, $8-\mathrm{EC} / \mathrm{FB} / \mathrm{ME}$ reactor, 9 $\mathrm{Fe} / \mathrm{C}, 10$ - electrode)

Where: the volume of wastewater tank was 3.5 liters. The volume of $\mathrm{EC} / \mathrm{FB} / \mathrm{ME}$ reactor was 0.66 liters. The electrocoagulation cell was a monopolar electrode having two electrodes (in Figure 1a) and four electrodes (in Figure 1b). The net spacing between two electrodes was $4.5 \mathrm{~cm}$ (in Figure 1a) and $1.4 \mathrm{~cm}$ (in Figure $1 \mathrm{~b}$ ). The particles of $\mathrm{Fe} / \mathrm{C}$ are put in the net spacing between electrodes.

\subsection{Methods}

The concentration of heavy metal ions was determined by an atomic absorption spectroscopy. Fluoride concentration was determined by using the ionometric standard method with a fluoride selective electrode [10]. Energy consumption was calculated from equation following [11]:

$$
P=U \times I \times t
$$

Where P - energy consumption (Wh); U - applied voltage (V); I - current intensity (A); t - time (hour).

By the orthogonal experiments study of the main factors influencing the efficiency of the treatment process, the factors and levels of experiments are shown in Table 1 and Table 2.

Table 1. Arrangement of orthogonal experiment $L_{16}\left(4^{5}\right)^{*}$

\begin{tabular}{lccccc}
\hline \multirow{2}{*}{ Level } & \multicolumn{5}{c}{ Factor } \\
\cline { 2 - 6 } & A & B & C & D & E \\
\hline 1 & 3 & 45 & 75 & 5 & $14-17$ \\
2 & 4 & 60 & 100 & 10 & $18-19$ \\
3 & 5 & 75 & 125 & 15 & $20-27$ \\
4 & 6 & 90 & 150 & 20 & $28-34$ \\
\hline
\end{tabular}

$* \mathrm{~L}_{16}\left(4^{5}\right)$ means 5 factors with 4 levels.

Where: A - initial $\mathrm{pH}, \mathrm{B}$ - hydraulic retention time (minute), $\mathrm{C}$ - mass of $\mathrm{Fe} / \mathrm{C}(\mathrm{g}), \mathrm{D}$ - applied voltage $(\mathrm{V})$ and $\mathrm{E}$ - particle diameter of $\mathrm{Fe} / \mathrm{C}$ (mesh). Other factors of the experiment are fixed such as distance of two electrodes of $4.5 \mathrm{~cm}$, wastewater 
speed of 260 liters/hour, initial concentration of copper and fluoride ion of $50 \mathrm{mg} / \mathrm{L}$.

Table 2. Arrangement of orthogonal experiment $L_{9}\left(3^{3}\right)^{* *}$

\begin{tabular}{lccc}
\hline \multirow{2}{*}{ Level } & \multicolumn{3}{c}{ Factor } \\
\cline { 2 - 4 } & L & M & N \\
\hline 1 & 20 & 30 & 3 \\
2 & 30 & 45 & 5 \\
3 & 40 & 60 & 7 \\
\hline
\end{tabular}

${ }^{* *} \mathrm{~L}_{9}\left(3^{3}\right)$ means 3 factors with 3 levels.

Where: L - hydraulic retention time (minute), $\mathrm{M}$ - mass of $\mathrm{Fe} / \mathrm{C}(\mathrm{g}), \mathrm{N}$ - applied voltage $(\mathrm{V})$. Other factors of the experiment are fixed such as distance of two electrodes of $1.4 \mathrm{~cm}$, wastewater speed of 260 liters/hour, particle diameter of $\mathrm{Fe} / \mathrm{C}$ of $20-27$ (mesh), initial $\mathrm{pH}$ of $5.0, \mathrm{KCl}$ of $0.5 \mathrm{~g} / \mathrm{L}$, initial concentrations of copper and fluoride ion of $50 \mathrm{mg} / \mathrm{L}$.

The experiments used aluminum electrodes which are added $\mathrm{KCl}$ of $0.5 \mathrm{~g} / \mathrm{L}$. Because the chloride salt added to the solution can prevent the formation of the alumina layer on the anode and therefore reduce the passivation problem of the electrode [12].

\section{Results and Discussion}

\subsection{Using EC/FB/ME Process with Two Electrodes}

In this section, effect of experimental factors on energy consumption and residual concentration of ions are examined by orthogonal experiments. The experiments are conducted based on Table 1 and orthogonal design of $\mathrm{L}_{16}\left(4^{5}\right)$ [4], and then use the variance analysis method to analyze results. Figure 2, Figure 3 and Figure 4 showed that experimental result:

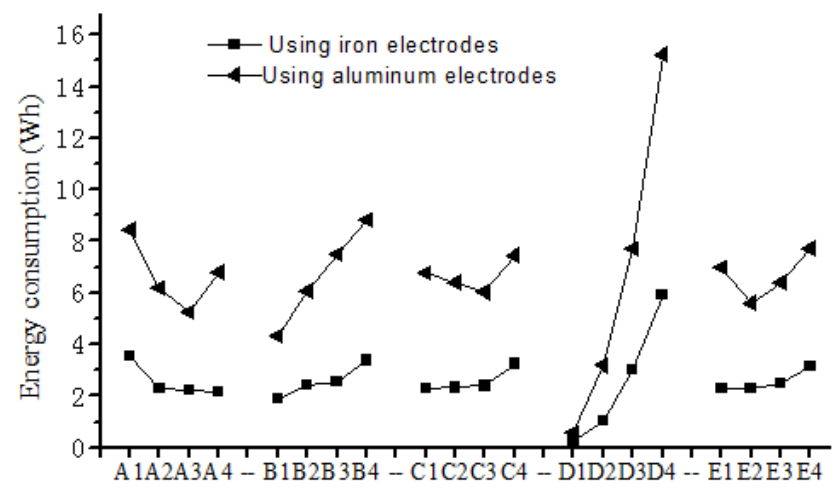

Figure 2. Relationship between experimental conditions and energy consumption

From Figure 2 noticed: Effect of factor D on energy consumption is largest. Therefore, we must be special attention to the factor $\mathrm{D}$ in choosing of the optimal condition for simultaneous removal of copper and fluoride ions. Energy consumption by the use of aluminum electrode is higher than iron electrode. Because the experiments used aluminum electrodes which are added $\mathrm{KCl}$, so the electrical conductivity of solutions is increased.

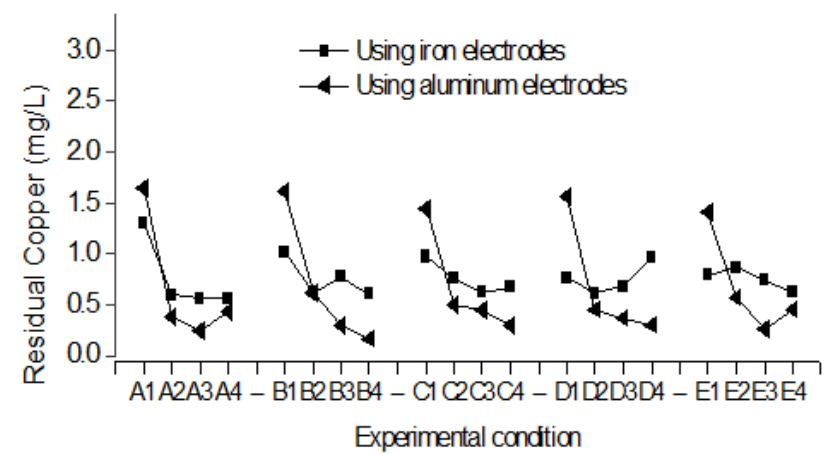

Figure 3. The relationship between experimental conditions and residual concentration of copper

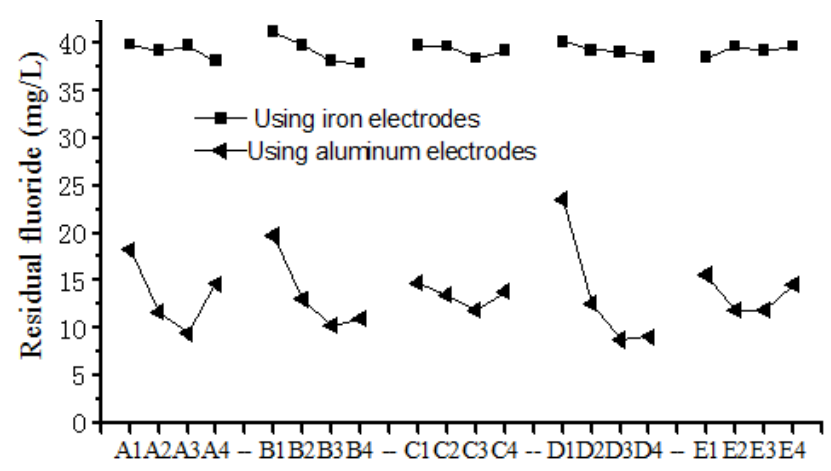

Experimental condition

Figure 4. The relationship between experimental conditions and residual concentration of fluoride

From Figure 3 noticed: The EC/FB/ME process treated copper ion from wastewater with removal efficiency very high. All of the $\mathrm{Cu}^{2+}$ concentration in the treated wastewater is less than $2 \mathrm{mg} / \mathrm{L}$. In the same experimental condition of level 2, 3 and 4 , the copper removal efficiency of aluminum electrodes is better than iron electrodes.

From Figure 4 noticed: The EC/FB/ME process using iron electrodes treated fluoride from wastewater with removal efficiency very low. But when using aluminum electrodes treated fluoride with removal efficiency very high.

The optimal condition for simultaneous removal of copper and fluoride from wastewater to achieve high performance and low energy consumption are chosen based on Figure 2, Figure 3 and Figure 4. The result indicated that the use of aluminum electrode is better than iron electrode. The best control parameters of $\mathrm{EC} / \mathrm{FB} / \mathrm{ME}$ process were achieved in initial $\mathrm{pH}$ of 5.0, a hydraulic retention time of 75 minutes, a mass of Fe/C of $125 \mathrm{~g}$, an applied voltage of $15 \mathrm{~V}$ and the particle diameter of $\mathrm{Fe} / \mathrm{C}$ of 20-27 mesh, respectively.

With this optimal condition and the initial concentration of ions of $50 \mathrm{mg} / \mathrm{L}$, the residual concentration of copper and fluoride ions in the treated wastewater is $0.030 \mathrm{mg} / \mathrm{L}$ and $7.655 \mathrm{mg} / \mathrm{L}$, respectively. Thus, copper ion was removed from wastewater with removal efficiency very high. But fluoride removal efficiency is not high. To overcome this weak point, the next experiment was the use of $\mathrm{EC} / \mathrm{FB} / \mathrm{ME}$ process with four aluminum electrodes (see Figure 1b).

\subsection{Using EC/FB/ME Process with Four Aluminum Electrodes}

In this section, effect of experimental factors on energy 
consumption and residual concentration of ions are examined by orthogonal experiments. The experiments are conducted based on Table 2 and orthogonal design of $L_{9}\left(3^{3}\right)$ [13], and then use the variance analysis method to analyze results. Experimental results are shown in Figure 5 and Figure 6.

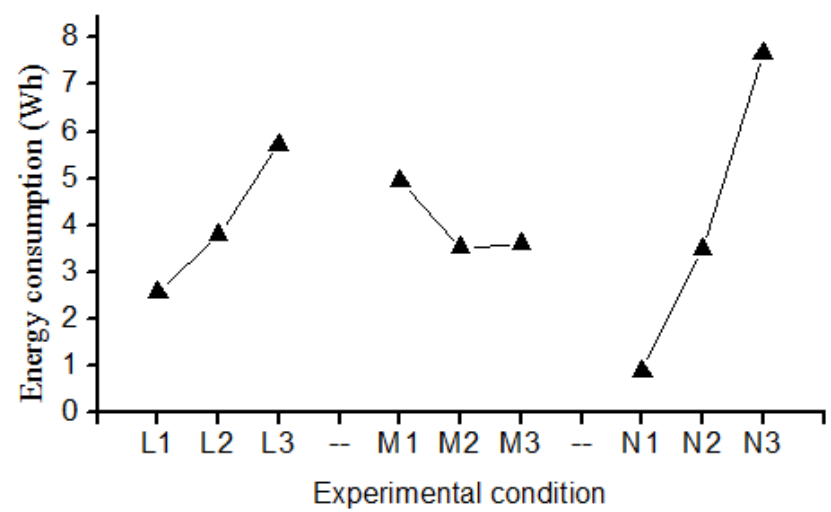

Figure 5. Relationship between experimental conditions and energy consumption

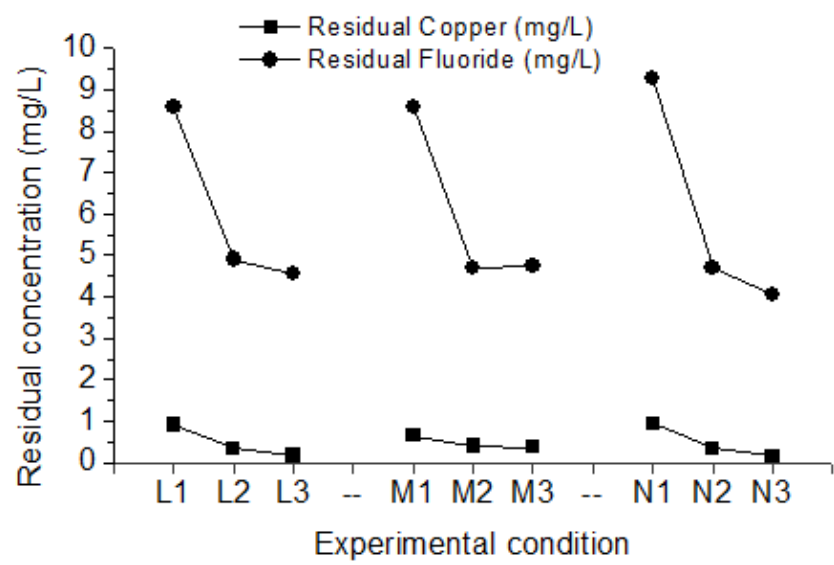

Figure 6. The relationship between experimental conditions and residual concentration of $\mathrm{Cu}^{2+}$ and $\mathrm{F}$

From Figure 6 noticed: copper removal efficiency is very high. All of the $\mathrm{Cu}^{2+}$ concentration in the treated wastewater is less than $1 \mathrm{mg} / \mathrm{L}$. In the same experimental condition, the removal efficiency of $\mathrm{Cu}^{2+}$ is better than fluoride. The optimal condition for simultaneous removal of copper and fluoride is $\mathrm{L}_{3} \mathrm{M}_{3} \mathrm{~N}_{3}$ or $\mathrm{L}_{3} \mathrm{M}_{2} \mathrm{~N}_{3}$.

From Figure 5 and Figure 6 noticed: energy consumption of $\mathrm{L}_{2}$ and $\mathrm{N}_{2}$ is much smaller than $\mathrm{L}_{3}$ and $\mathrm{N}_{3}$. But the ions removal efficiency of $\mathrm{L}_{2}$ and $\mathrm{N}_{2}$ is not much smaller than $\mathrm{L}_{3}$ and $\mathrm{N}_{3}$. In addition, when the use of factor $\mathrm{N}_{3}$ is aluminum electrodes very hot and therefore is not safe for experimental equipments. Thus, the optimal condition for simultaneous removal of copper and fluoride from wastewater to achieve high performance and low energy consumption is $\mathrm{L}_{2} \mathrm{M}_{2} \mathrm{~N}_{2}$ with a hydraulic retention time of 30 minutes, a mass of $\mathrm{Fe} / \mathrm{C}$ of $45 \mathrm{~g}$ and an applied voltage of $5 \mathrm{~V}$, respectively.

With this optimal condition and the initial concentration of ions of $50 \mathrm{mg} / \mathrm{L}$, the residual concentration of copper and fluoride ions in the treated wastewater is $0.205 \mathrm{mg} / \mathrm{L}$ and $2.936 \mathrm{mg} / \mathrm{L}$, respectively.

Thus, the EC/FB/ME process with four aluminum electrodes for fluoride removal efficiency is much better than $\mathrm{EC} / \mathrm{FB} / \mathrm{ME}$ process with two aluminum electrodes.

\subsection{Current Efficiency}

The current efficiency is defined as the ratio of the actual electrode consumption to the theoretical value. It is an important parameter in the electrocoagulation process because it affects the lifetime of the electrode. So, the both values, theoretical and experimental, consumed electrode are determined. The first one is calculated using Faraday's law [14, 15]:

$$
m_{F e}=A I t / n F
$$

Where A - molecular weight (g/mol); I - current intensity (A); $\mathrm{t}$ - time (s); F - Faraday's constant (96500 C); n - the number of electrons corresponding to aluminum oxidation.

The experiment for simultaneous removal of copper and fluoride ions from wastewater are conducted in four aluminum electrodes, initial $\mathrm{pH}$ of 5.0, a hydraulic retention time of 30 minutes, a mass of $\mathrm{Fe} / \mathrm{C}$ of $45 \mathrm{~g}$, an applied voltage of $5 \mathrm{~V}$ and the particle diameter of $\mathrm{Fe} / \mathrm{C}$ of $20-27$ mesh, the initial concentration of copper and fluoride ion of $50 \mathrm{mg} / \mathrm{L}$. The result is shown that the current efficiency was $174.45 \%$. This value is in the middle of the range of $120 \%-220 \%$ reported in a recent study [16]. Thus, the actual aluminum electrode consumption is much larger than faradaic aluminum dosing. Because besides the electrochemical corrosion of the anode, also happened chemical corrosion of both the anode and cathode [2]. This is beneficial because it reduces wastewater treatment time.

\subsection{Effect of Initial Concentration}

To test the effect of initial concentration of copper and fluoride on the ions removal efficiency of the EC/FB/ME process, a set of experiments was conducted with three different solutions containing same concentrations of 10,50 and $200 \mathrm{mg} / \mathrm{L}$ of each ion respectively. These experiments were conducted in four aluminum electrodes, an initial $\mathrm{pH}$ of 5.0, a hydraulic retention time of 30 minutes, a mass of $\mathrm{Fe} / \mathrm{C}$ of $45 \mathrm{~g}$, an applied voltage of $5 \mathrm{~V}$ and the particle diameter of $\mathrm{Fe} / \mathrm{C}$ of 20-27 mesh. The experimental results are shown in Figure 7.
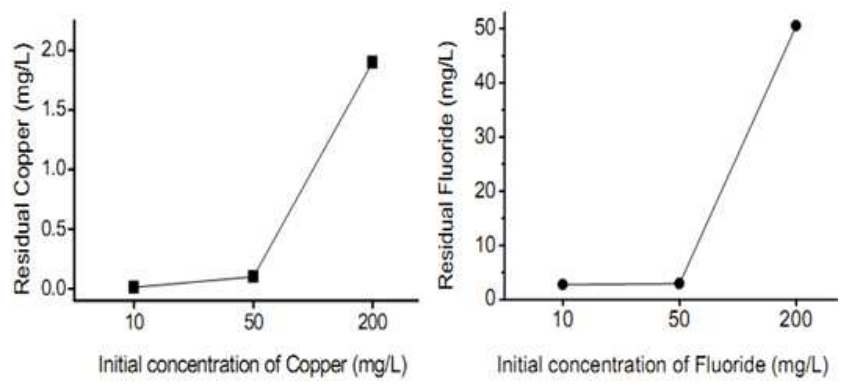

Figure 7. Effect of initial concentration of copper and fluoride on removal efficiency.

From Figure 7 noticed: if the initial concentration of copper is less than $50 \mathrm{mg} / \mathrm{L}$, the residual concentration of copper in the treated wastewater will be less than $0.5 \mathrm{mg} / \mathrm{L}$. If the initial concentration of copper is $200 \mathrm{mg} / \mathrm{L}$, the residual concentration of copper in the treated wastewater will be $2.0 \mathrm{mg} / \mathrm{L}$. Thus, this $\mathrm{EC} / \mathrm{FB} / \mathrm{ME}$ process is suitable for treatment of wastewater that copper concentration is less than $200 \mathrm{mg} / \mathrm{L}$. 
Figure 7 was also shown that, this $\mathrm{EC} / \mathrm{FB} / \mathrm{ME}$ process is suitable for treatment of wastewater that fluoride concentration is less than $50 \mathrm{mg} / \mathrm{L}$.

\subsection{Treatment of Actual Wastewater}

The applicability of the EC/FB/ME process for actual wastewater was validated by treating a smelting wastewater sample. The main characteristics of the effluent sample before and after treatment are shown in Table 3.

Table 3. Characteristics of the smelting wastewater before and after treatment by the $E C / F B / M E$ process.

\begin{tabular}{lccc}
\hline Parameter & $\begin{array}{c}\text { Before } \\
\text { treatment }\end{array}$ & $\begin{array}{c}\text { After } \\
\text { treatment }\end{array}$ & Removal rate (\%) \\
\hline $\mathrm{pH}$ & 5.00 & 6.11 & \\
$\mathrm{Cu}(\mathrm{mg} / \mathrm{L})$ & 4.680 & $<0.001$ & 100 \\
$\mathrm{~F}(\mathrm{mg} / \mathrm{L})$ & 22.177 & 3.833 & 82.7 \\
$\mathrm{~Pb}(\mathrm{mg} / \mathrm{L})$ & 3.046 & $<0.001$ & 100 \\
$\mathrm{As}(\mathrm{mg} / \mathrm{L})$ & 1.302 & 0.004 & 99.7 \\
\hline
\end{tabular}

From table 3 found that, the residual concentrations of heavy metal and fluoride are lower than the emission standards of pollutants. Thus, the EC/FB/ME process is a safe, reliable and efficient method for removal of heavy metals and fluoride from smelting wastewaters.

\subsection{Analysis of Mechanism}

In the EC/FB/ME process, the removal of copper ion depends on redox and adsorption. Copper ion, beyond hydroxide precipitation and absorption on the $\mathrm{Al}(\mathrm{OH})_{3}$, $\mathrm{Al}(\mathrm{OH})^{2+}, \mathrm{Al}(\mathrm{OH})_{2}{ }^{+}, \mathrm{Fe}(\mathrm{OH})_{2}, \mathrm{Fe}(\mathrm{OH})_{3}, \mathrm{Fe}(\mathrm{OH})_{4}{ }^{-}$flocs, is also partially removed by direct electroreduction at the cathode or by electroless deposition according to the reaction as follows as $[11,17]$ :

$$
\begin{gathered}
3 \mathrm{Cu}^{2+}+2 \mathrm{Al} \rightarrow 2 \mathrm{Al} l^{3+}+3 \mathrm{Cu} \downarrow \\
\mathrm{Cu}^{2+}+\mathrm{Fe} \rightarrow \mathrm{Fe}^{2+}+\mathrm{Cu} \downarrow
\end{gathered}
$$

$\mathrm{Cu}$ generated from the reaction was adsorbed on the carbon surface of $\mathrm{Fe} / \mathrm{C}$ and the aluminum cathode surface or deposited with coagulants; thus, it can be removed from wastewater.

The mechanism of the fluoride removal process was a chemical adsorption process with $\mathrm{F}^{-}$replacing the $\mathrm{OH}^{-}$group from the $\mathrm{Al}_{\mathrm{n}}(\mathrm{OH})_{3 \mathrm{n}}$ and $\mathrm{Fe}_{\mathrm{n}}(\mathrm{OH})_{3 \mathrm{n}}$ flocs. Because the affinity between fluoride and $\mathrm{Fe}(\mathrm{OH})_{3}$ is much smaller than that of $\mathrm{Al}(\mathrm{OH})_{3}[18,19]$, so fluoride removal efficiency of the iron electrode is much smaller than the aluminum electrode. Fluoride ions and hydroxide ions can clearly co-precipitate with $\mathrm{Al}^{3+}$ ions to form $\mathrm{Al}_{n} \mathrm{~F}_{\mathrm{m}}(\mathrm{OH})_{3 \mathrm{n}-\mathrm{m}}[18]$ :

$$
n A l^{3+}+(3 n-m) O H^{-}+m F^{-} \rightarrow A l_{n} F_{m}(O H)_{3 n-m} \downarrow
$$

However, the fluoride ions in the precipitate are very easily substituted for hydroxide ions.

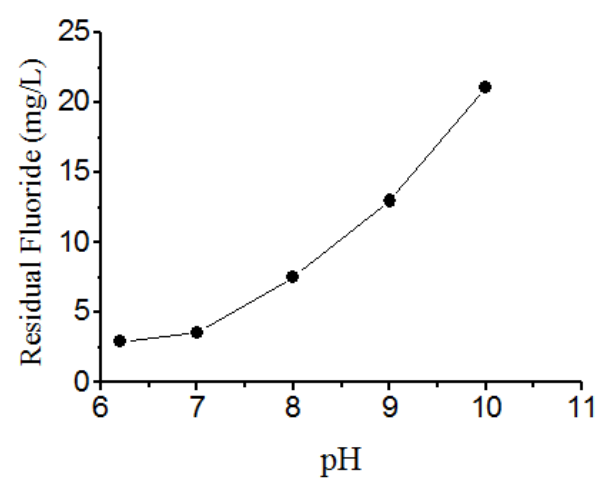

Figure 8. Effect of pH on residual concentration of fluoride

(This experiment is conducted at the optimal condition of the EC/FB/ME process for removal of copper and fluoride from wastewater, and then used $\mathrm{NaOH}$ to adjust the solution $\mathrm{pH}$ value, initial concentration of fluoride $=50 \mathrm{mg} / \mathrm{L}$ ).

Figure 8 was shown that, when the solution $\mathrm{pH}$ value is lager than $7, \mathrm{OH}^{-}$group easily replaces $\mathrm{F}^{-}$from the $\mathrm{Al}_{\mathrm{n}} \mathrm{F}_{\mathrm{m}}(\mathrm{OH})_{3 \mathrm{n}-\mathrm{m}}$ flocs, the reaction as follows as:

$$
A l_{n} F_{m}(O H)_{3 n-m} \downarrow+x O H^{-} \rightarrow A l_{n} F_{m-x}(O H)_{3 n-m+x} \downarrow+x F^{-}
$$

\subsection{Comparison of EC/FB/ME Process and Electrocoagulation (EC) Process}

A test was conducted to compare the $\mathrm{EC} / \mathrm{FB} / \mathrm{ME}$ process and EC process at the same of experimental conditions, such as using four aluminum electrodes, an initial $\mathrm{pH}$ of 5.0, a hydraulic retention time of 30 minutes, an applied voltage of $5 \mathrm{~V}$, the initial concentration of $\mathrm{Cu}^{2+}$ and $\mathrm{F}^{-}$of $50 \mathrm{mg} / \mathrm{L}, \mathrm{KCl}$ $0.5 \mathrm{~g} / \mathrm{L}$, etc. The experimental result was shown in Figure 9.

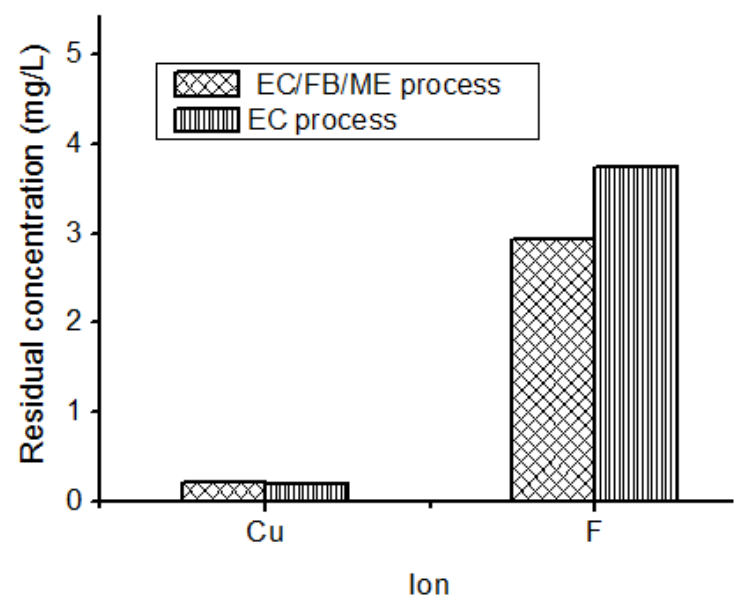

Figure 9. Comparison of residual concentration of $\mathrm{Cu}^{2+}$ and $\mathrm{F}$ between the $E C / F B / M E$ process and EC process.

Figure 9 was shown that, the EC/FB/ME process significantly outperformed EC process for fluoride removal. But copper removal efficiency of the two processes is equivalent. The cause can be explained as follows as: $\mathrm{Fe}^{3+}$ is good coagulants. It is frequently used as co-coagulant with aluminum salt. Fengsheng, et al [18] have demonstrated that $50 \mathrm{mg} / \mathrm{L}$ of iron ion in the EC process gives the best fluoride removal. Too low or high $\mathrm{Fe}^{3+}$ concentration are not good for fluoride removal of the $\mathrm{EC}$ process. In this $\mathrm{EC} / \mathrm{FB} / \mathrm{ME}$ process, 
$\mathrm{Fe}^{3+}$ concentration is $67 \mathrm{mg} / \mathrm{L}$, so fluoride removal efficiency is better than EC process. But too high $\mathrm{Fe}^{3+}$ concentration may lead to the precipitation of $\mathrm{Fe}(\mathrm{OH})_{3}$ onto the $\mathrm{Al}(\mathrm{OH})_{3}$ flocs surface, the $\mathrm{Fe}(\mathrm{OH})_{3}$ precipitates blind the $\mathrm{Al}(\mathrm{OH})_{3}$ flocs [18-19].

Recently, some of scientific literatures reported that the EC process performed better than $\mathrm{CC}$ (chemical coagulation) process in defluoridation efficiency [20-23]. Thus, the $\mathrm{EC} / \mathrm{FB} / \mathrm{ME}$ process is the best suitable for treatment of fluoride ion in wastewater.

\section{Conclusion}

The optimal condition of the EC/FB/ME process for simultaneous removal of copper and fluoride from wastewater was achieved in four aluminum electrodes, an initial $\mathrm{pH}$ of 5.0, a hydraulic retention time of 30 minutes, a mass of $\mathrm{Fe} / \mathrm{C}$ of $45 \mathrm{~g}$, an applied voltage of $5 \mathrm{~V}$ and the particle diameter of $\mathrm{Fe} / \mathrm{C}$ of 20-27mesh. This EC/FB/ME process is suitable for treatment of wastewater that fluoride concentration is less than $50 \mathrm{mg} / \mathrm{L}$ and copper concentration is less than $200 \mathrm{mg} / \mathrm{L}$. The effluent wastewater by this process is very clear and its quality exceeds the direct discharge standard.

\section{References}

[1] T. A. Kurniawan, G. Y. S. Chan, W. H. Lu, S. Babel, "Physico-chemical treatment techniques for wastewater laden with heavy metals," Chemical Engineering Journal, 2006, 118, pp. 83-98.

[2] Zh. Gu, Zh. H. Liao, M. Schulz, J. R. Davis, J. C. Bagents, J. Farrell, "Estimating Dosing Rates and Energy Consumption for Electrocoagulation Using Iron and Aluminum Electrodes," Ind. Eng. Chem. Res., 2009, 48, pp. 3112-3117.

[3] U. Kurt, M. T. Gonullu, F. Ilhan, K. Varinca, "Treatment of domestic wastewater by Electrocoagulation in a cell with $\mathrm{Fe}-\mathrm{Fe}$ electrodes," Environmental Engineering Science, 2008, 25(2), pp. 153-162.

[4] Y. F. Zhou, M. Liu, Q. Wu, "Water quality improvement of a lagoon containing mixed chemical industrial wastewater by micro-electrolysis-contact oxidization," Journal of Zhejiang University-Science A (Applied Physics \& Engineering), 2011, 12 (5), pp. 390-398.

[5] M. Kobya, O. T. Can, M. Bayramoglu, "Treatment of textile wastewaters by Electrocoagulation using iron and aluminium electrodes," Journal of Hazardous Materials, 2003, B 100, pp. 163-178.

[6] N. Adhoum, L. Monser, "Decolourization and removal of phenolic compounds from olive mill wastewater by Electrocoagulation," Chemical engineering and Processing, 2004, 43, pp. 1281-1287.

[7] J. Nouri, A. H. Mahvi, E. Bazrafshan, "Application of Electrocoagulation process in removal of zinc and copper from aqueous solutions by aluminium electrodes," International Journal of Environmental Research, 2010, 4, pp. 201-208.

[8] J. J. Yang, X. J. Xu ,G. Wang, W. Pan, H. Z. Yu, G. T. Zhen, T. Rui, "Treatment of zinc and lead smelting wastewater containing heavy metals by combined process of microelectrolysis with flocculation," The Chinese jounal of nonferrous metals, 2012, 22(7), pp. 2125-2132.

[9] X. L. Dai, "Study on the treatment of chromium-containing wastewater of galvanization by utilizing the technology of micro-electrolysis and its application," Industrial water treatment, 2005, 25(1), pp. 69-71.

[10] AWWA and WEF, "Standard Methods for the Examination of Water and Wastewater," American Water Works Association and Water Environment Federation, Washington, D.C, 1998.

[11] D. Konstantinos, A. Christoforidis, E. Valsamidou, "Removal of nickel, copper, zinc and chromium from synthetic and industrial wastewater by Electrocoagulation," International Journal of Environmental Sciences, 2011, 1(5), pp. 697-710.

[12] N. Mameri, A. R. Yeddou, H. Lounici, D. Belhocine, H. Grib, B. Bariou, "Defuorination of septentrional Sahara water of North Africa by Electrocoagulation process using bipolar aluminium electrodes," Water Research, 1998, 32(5), pp. 1604-1612.

[13] K. Chomsamutr, S. Jongprasithporn, "Optimization parameters of tool life model using the Taguchi approach and response surface methodology," IJCSI International Journal of Computer Science, 2012, 9, 1(3), pp. 120-125.

[14] Z. Zaroual, M. Azzi, N. Sai, E. Chainet, "Contribution to the study of Electrocoagulation mechanism in basic textile effluent," Journal of Hazardous Materials, 2006, 131(1-3), pp. 73-78.

[15] P. T. Bolger and D. C. Szlag, "Electrochemical treatment and reuse of nickel plating rinse waters," Environmental Progress, 2004, 21, pp. 203-208.

[16] T. Picard, G. C. Feuillade, M. Mazet, C. Vandensteendam, "Cathodic dissolution in the electrocoagulation process using aluminum electrodes," J. En iron. Monit. , 2000, 2, pp. 77-80.

[17] M. M. Emamjomeh, M. Sivakumar, "Denitrification using a monopolar Electrocoagulation/flotation (ECF) process," Journal of Environmental Management, 2009, 91, pp. 516-522.

[18] F. Shen, X. M. Chen, P. Gao, G. H. Chen, "Electrochemical removal of fluoride ions from industrial wastewater," Chemical Engineering Science, 2003, 58, pp. 987 - 993.

[19] C. Hicyilmaz, S. Bilgen, K. E. Ozbas, "The effect of dissolved species on hydrophobic aggregation of fluorite," Colloids and Surfaces, 1997, 121, pp. 15-21.

[20] J. Zhu, H. Zh. Zhao, J. R. Ni, "Fluoride distribution in Electrocoagulation defluoridation process," Elsevier Separation and Purification Technology, 2007, 56, pp. 184-191.

[21] C.Y. Hu, S.L. Lo, W.H. Kuan, "Effects of co-existing anions on fluoride removal in electrocoagulation (EC) process using aluminum electrodes," Water Res. , 2003, 37, pp. 4513-4523.

[22] M. Lui, R.Y. Sun, J.H. Zhang, Y. Bina, L. Wei, "Elimination of excess fluoride in potablewaterwith coarcervation by electrolysis using aluminum anode," Fluoride, 1983, 20, pp. $54-63$.

[23] C. Y. Hu, S. L. Lo, W. H. Kuan, "Effects of themolar ratio of hydroxide and fluoride to $\mathrm{Al}(\mathrm{III})$ on fluoride removal by coagulation and electrocoagulation," J. Colloid Interface Sci., 2005, 283, pp. 472-476. 